\title{
Wspomnienie o Pani Profesor Barbarze Gwiazdowskiej (1927-2011)
}

\author{
Członku Honorowym PTFM \\ Konsultancie Ministra Zdrowia w dziedzinie fizyki medycznej
}

Pani Profesor Barbara Gwiazdowska urodziła się w Warszawie w rodzinie inżyniera budowy mostów Stanisława Godziny, cywilnego pracownika Wojska Polskiego. W 1938 r. rodzina zamieszkała $w$ Łodzi, dokąd ojciec został służbowo przeniesiony do Dowództwa Okręgu Korpusu 4.

Tutaj przeżyła wyjątkowo dramatycznie wybuch wojny, a zwłaszcza okupację niemiecką: wysiedlenie, rewizje, głód, uwięzienie ojca i osadzenie go w obozie eksterminacyjnym na Radogoszczy.

Po wyzwoleniu, w lutym 1945 roku, zdała egzamin do trzeciej klasy gimnazjum. Skończyła liceum typu matematyczno-fizycznego i rozpoczęła studia na Wydziale Elektrycznym Politechniki Łódzkiej. Po dwóch latach przeniosła się na Politechnikę Warszawską na taki sam Wydział, gdzie prof. Cezary Pawłowski, uczeń i współpracownik Marii Skłodowskiej-Curie, utworzył i zorganizował specjalizację pod nazwą „elektrotechnika medyczna”. Było to jedyne wówczas w Polsce, a także na świecie, miejsce gdzie kształcono inżynierów mających pracować $w$ środowisku szpitalnym. Specjalność była prekursorem fizyki medycznej na Uniwersytecie Warszawskim i kierunku studiów technicznych: inżynierii biomedycznej uprawianego początkowo na Politechnice Warszawskiej, a z czasem także na innych Politechnikach.

Pracę magisterską pod kierunkiem prof. Pawłowskiego wykonywała w Zakładzie Fizyki Instytutu Radowego, gdzie rozpoczęła pracę jeszcze przed jego ukończeniem (1952). W tym samym roku wyszła za mąż za Bogdana Gwiazdowskiego, kolege ze studiów. 
W roku 1966 obroniła doktorat. Habilitowała się w 1985 r.

Na przełomie lat 1968 i 1969 odbyła roczny staż szpitalny w Wielkiej Brytanii. W 1972 roku została kierownikiem Zakładu Fizyki Medycznej Instytutu.

Na uwagę zasługuje jej zaangażowanie w działalność społeczną. Kiedy w 1965 r. mgr Oskar Chomicki, fizyk zajmujący się zastosowaniami izotopów w medycynie, podjął inicjatywę utworzenia Polskiego Towarzystwa Fizyki Medycznej, bez wahania zadeklarowała współpracę i pomoc organizacyjną w tym dalekowzrocznym przedsięwzięciu, ważnym naukowo i społecznie. Znalazła się $w$ nielicznym gronie członków założycieli. Niezwykle aktywnie zaangażowała się $w$ działalność nowo powstałego Towarzystwa. W szczególności przy organizacji Zjazdów Towarzystwa, a zwłaszcza Międzynarodowych Szkół dla fizyków z tak zwanego wschodniego bloku, na które zapraszano, jako wykładowców, najwybitniejszych fizyków medycznych z całego świata.

Była także inicjatorką i propagatorką utworzenia na Wydziale Fizyki Uniwersytetu Warszawskiego specjalności „fizyka medyczna”, co nie było proste ani łatwe. Większość ówczesnych fizyków uważało, że fizyka jest jedna i nie może mieć przymiotnika określającego obszar jej zastosowania. Poparcie wybitnych przedstawicieli naukowego środowiska medycznego, w tym Komitetu Fizyki Medycznej PAN oraz organizacji społecznych, w tym PTFM, wpłynęło na zmianę stanowiska UW. Specjalność fizyka medyczna stała się faktem. Wykształcono $w$ tej specjalności kilkuset fizyków medycznych. Wielu doktoryzowało i habilitowało się na podstawie dorobku naukowego z obszaru fizyki medycznej.

Powstanie tej specjalności, pierwszej w Polsce (1974), Pani Profesor uznawała za swoje największe osiągnięcie.

Ma swój wielki udział $w$ utworzeniu czasopisma naukowego Postępy Fizyki Medycznej (obecnie Polish Journal of Medical Physics and Engineering).

W latach 1986-1989 profesor Gwiazdowska była prezesem Towarzystwa.

Od początku lat dziewięćdziesiątych, $\mathrm{z}$ wyboru środowiska naukowego została członkiem, a następnie prze wiele lat była wiceprzewodniczącą Komitetu Fizyki Medycznej Polskiej Akademii Nauk, założonego przez prof. Witolda Zawadowskiego przy współudziale prof. Cezarego Pawłowskiego (obecnie Komitet Fizyki Medycznej, Radiobiologii i Diagnostyki Obrazowej).

Po przystąpieniu do Unii Europejskiej Polska została zobowiązana m.in. do przyjęcia zasady, aby fizycy medyczni oraz inżynierowie medyczni pracujący w szpitalach, biorący 
udział $w$ procedurach diagnostycznych i terapeutycznych wobec pacjenta, mieli tytuł specjalisty $w$ dziedzinach fizyki medycznej lub inżynierii medycznej. Przyjęto, że tytuł ten uzyskiwany będzie na zasadach podobnych do stosowanych $w$ specjalizacjach medycznych, to znaczy, że odpowiednie przeszkolenie będzie prowadzone przez instytucje powoływane przez organy rządowe (Centrum Medyczne Kształcenia Podyplomowego). Tytuł specjalisty nadawany byłby przez Ministra Zdrowia.

Idea została wprowadzona $w$ życie Rozporządzeniem Ministra Zdrowia $\mathrm{z}$ dnia 30.09.2002 w sprawie uzyskania tytułu specjalisty $w$ dziedzinach mających zastosowanie w ochronie zdrowia (Dz. U. Nr 173, poz. 1419).

Merytoryczne rozwinięcie Rozporządzenia dotyczące opracowania programów kształcenia wzięła na swoje barki Pani Profesor. W niewielkim gronie współpracowników w krótkim czasie przygotowała Program Specjalizacji w dziedzinie fizyki medycznej. Podjęła się niewyobrażalnie trudnego zadania i wykonała je znakomicie.

Weszła następnie do Zespołu Ekspertów Ministra zdrowia, mającego nadzorować prawidłowość realizacji procedur uzyskiwania tytułu specjalisty. Kilka miesięcy potem została powołana (2004 r.) na funkcję Konsultanta Krajowego $w$ dziedzinie fizyki medycznej i inżynierii medycznej. W tej drugiej dziedzinie na okres przejściowy do czasu wyłonienia właściwego kandydata.

Prof. Barbara Gwiazdowska miała duży dorobek naukowy, dydaktyczny i organizacyjny. Była promotorką trzech doktorów. Była człowiekiem wybitnym, specjalistką w zakresie fizyki medycznej, kierowniczką i reformatorką Zakładu Fizyki Medycznej Instytutu Onkologii (w duchu przystosowania jego funkcji do nowoczesnych środków radiodiagnostyki, radioterapii i rosnących wymagań medycyny), współtwórczynią Polskiego Towarzystwa Fizyki Medycznej, jego przewodniczącą i aktywną wiceprzewodniczącą Komitetu Fizyki Medycznej, Radiobiologii i Diagnostyki Obrazowej, oraz pierwszym $w$ historii fizyki medycznej konsultantem krajowym.

Przede wszystkim jednak Pani Profesor była uroczą kobietą: mądrym, prawym i skromnym człowiekiem, życzliwym ludziom. Pomagała potrzebującym pomocy, wspierała każdego, kto o to poprosit: kolegów, współpracowników, studentów i pacjentów. Dla każdego miała miłe słowo i dobrą radę. Cieszyła się w naszym środowisku wielkim autorytetem.

Grzegorz Pawlicki

Oskar Chomicki

Wojciech Bulski 